\title{
Pelatihan Pembuatan Kerajinan dengan Bahan Dasar Tulang Daun melalui Proses Dekomposisi
}

\author{
Handicraft Making Training with Leaf Bone Basic Materials through the Decomposition \\ Process
}

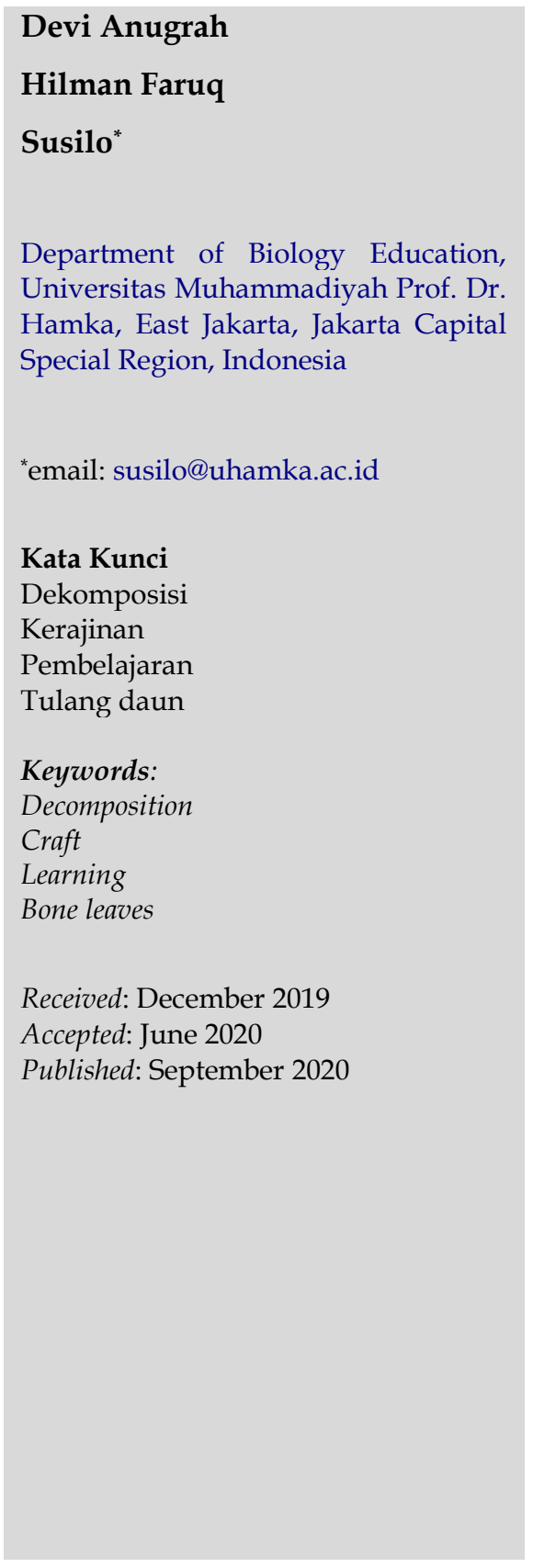

\begin{abstract}
Abstrak
Kurikulum 2013 mengharuskan materi pembelajaran dapat meningkatkan kompetensi pengetahuan, keterampilan, dan sikap untuk menciptakan sebuah karya yang bernilai. Kegiatan membuat kerajinan tangan berbahan tulang daun yang didekomposisi ini adalah salah satu contoh konkret untuk memenuhi capaian kurikulum 2013. Selain membantu memahami pelajaran biologi, kegiatan membuat kerajinan dari tulang daun dapat menumbuhkan jiwa kewirausahaan bagi siswa. Oleh karena itu, dalam kegiatan pengabdian masyarakat ini pelatihan membuat kerajinan dari tulang daun diberikan kepana guru dan siswasiswi di SMA N 1 dan SMP 2 Banyuputih, Situbondo. Pelatihan diikuti oleh 23 siswa dan 1 guru di SMA N 1 dan dam 20 siswa dan 1 guru SMP 2 Banyuputih, Situbondo. Pelatihan dilaksanakan dengan metode penyampaian materi dan praktek langsung. Selama kegiatan juga dilakukan dengan diskusi secara langsung dengan peserta. Hasil kegiatan pelatihan ini menunjukkan bahwa semua peserta mendapat pengetahuan dan keterampilan baru yaitu cara membuat kerajinan berbahan tulang daun. Kerajinan berbahan tulang tulang daun sangat diminati siswa karena siswa dapat mengetahui struktur tulang secara langsung. Kegiatan pengabdian ini memberikan wawasan baik kepada siswa maupun kepada guru untuk memanfaatkan kearifan lokal disekitar agar lebih bernilai guna.
\end{abstract}

\begin{abstract}
The 2013 curriculum requires learning materials to improve the competence of knowledge, skills, and attitudes to create valuable work. This decomposed leaf bone handicraft activity is a concrete example of fulfilling 2013 curriculum achievements. Besides helping to understand biology lessons, the activity of making leaf bone crafts can foster an entrepreneurial spirit for students. Therefore, in this community service activity, training to make handicrafts from leaf bones is given to teachers and students in SMA N 1 and SMP 2 Banyuputih, Situbondo. The training was attended by 23 students and one teacher at SMA N 1 and dam 20 students and one teacher at SMP 2 Banyuputih, Situbondo. The training is carried out by the method of delivering material and direct practice. The activity was also carried out with direct discussion with participants. The results of this training activity showed that all participants gained new knowledge and skills, namely how to make crafts made from leaf bones. Craft made of leaf bone is very attractive to students because students can know the bone structure directly. This dedication activity provides insight to both students and teachers to take advantage of local wisdom around it to be more valuable.
\end{abstract}




\section{PENDAHULUAN}

Kurikulum 2013 yang berlaku sekarang ini mengharuskan pendidikan di Indonesia terus memperbaharui sistem pembelajaran agar tidak ketinggalan jaman. Dalam menghadapi era industri 4.0 ini, pemerintah melalui Kementerian Pendidikan dan Kebudayaan selalu menyuarakan agar pendidikan menghasilkan lulusan yang siap berinovasi dalam beradaptasi dengan kemajuan jaman (Wardina et al., 2019). Setiap lulusan diharapkan tidak lagi menjadi pekerja namun mampu menciptakan pekerjaannya sendiri agar mampu bersaing di kanca global. Wing et al. (1999) menganalisis keterampilan dan kompetensi siswa untuk menghadapai dunia kerja di abad ke-21. Tujuh ketrampilan yang ditekankan salah satunya adalah ketrampilan inisiatif atau inovatif dan berjiwa entrepreneur (Trilling \& Fadel, 2009).

Salah satu cara untuk meningkatkan inisiatif dan berjiwa entrepreneur adalah dengan membekali siswa dengan ketrampilan membuat kerajinan tangan (Wahyuni \& Hidayati, 2017). Mata pelajaran biologi di tingkat SMP dan SMA, telah diberikan materi tentang struktur tumbuhan yaitu daun dan bagian-bagiannya. Sebagai implementasi dari materi tersebut, siswa dapat terbantu dengan membuat awetan tulang daun. Dengan membuat awetan tulang daun ini, siswa akan melihat secara langsung struktur tulang-tulang daun secara nyata. Lebih lanjut mereka dapat memanfaatkan keunikan tulang-tulang daun tersebut menjadi sebuah karya kerajinan yang menawan (Muhajirin, 2018).

Pola pertulangan yang unik dapat dijadikan kerajinan yang menawan dan memiliki nilai ekonomis lebih. Kerajinan tangan tulang daun apabila dibuat dengan baik dapat menjadi hiasan rumah. Daun yang digunakan untuk membuat kerajianan ini adalah daun yang mempunyai pertulangan utuh dari cabang tulang daun hingga vena-vena tulang daun sehingga tetap mempertahankan bentuk daun tersebut (Sarjani et al., 2017).

Melihat kondisi yang ada pada SMP 2 dan SMAN 1 di Banyuputih, para siswa belum pernah dibekali ketrampilan membuat kerajinan berbahan tulang daun. Padahal bahan-bahan yang digunakan cukup mudah didapat dan ada disekitar mereka. Dari hasil wawancara dengan guru di kedua mitra tersebut, ternyata kerajinan seperti ini sangat diperlukan bagi siswa-siswa. Selain di Laboratorium, pengetahuan dan skill siswa sangat penting dan dapat diasah dengan memberikan pelatihan-pelatihan salah satunya adalah kerajinan tangan. Guru sebagai penggerak proses pembelajaran yang akan dikuasai siswa juga harus mampu menciptakan dan memberikan inovasi kepada siswa (Susilo \& Amirullah, 2018). Berdasarkan wawancara sebelumnya, para guru juga sangat tertarik untuk mempelajari pembuatan kerajinan berbahan dasar daun tersebut karena belum pernah atau belum mendapatkan pengetahuan tersebut. Data siswa di SMP 2 Banyuputih menunjukkanjumlah siswa total adalah 427 siswa dan 25 guru. Sementara jumlah siswa total di SMAN 1 Banyuputih 133 siswa dan 15 guru. Jumlah tersebut sangat berpeluang untuk menciptakan berbagai kreasi dan inovasi proses pembelajaran.

\section{METODOLOGI}

Berdasarkan permasalahan yang dihadapi, tujuan dilakukan pengabdian ini adalah untuk membantu guru dan siswa meningkatkan ketrampilan melalui kerajianan tangan. Kegiatan PKM ini dilaksanakan selama 2 hari yang bertempat di SMP 2 dan SMAN 1 di Banyuputih, Situbondo, Jawa Timur. Sebelum pelaksanaan, tim melakukan observasi dan beriskusi terkait materi dan pelaksanaan. Kegiatan PkM ini dilakukan dengan metode ceramah dan praktek. Merujuk dari solusi yang 
ditawarkan, berikut adalah langkah-langkah yang dilakukan:

\section{Hari pertama}

Pada hari pertama, para peserta diberikan materi tentang pentingnya pengetahuan alam dan pemanfaatan lingkungan sekitar dengan bijak. Hal ini sangat penting karena sebagai dasar dalam memaksimalkan lingkungan agar bernilai lebih tanpa merusak atau mengganggu keseimbangan alam. Penyampaian materi diberikan oleh narasumber dengan metode ceramah secara klasikal pada sesi pertama. Pada sesi kedua, para peserta baik guru dan siswa diberikan pelatihan praktek secara langsung dikelas yaitu cara mengolah bahanbahan berupa daun yang telah berguguran untuk mendapatkan tulang daunnya. Daun yang tinggal sisa tulangnya ini akan dimanfaatkan untuk membuat kerajinan yang unik. Materi tersebut diberikan oleh narasumber Yuni Astuti, M.Pd.

\section{Harikedua}

Hari kedua diisi dengan melanjutkan pekerjaan sebelumnya yaitu tulang daun yang didaptkan dibentuk menjadi berbagi kerajinan. Penyampaian materi akan dilakukkan oleh Hilman Faruq, M.Pd dan Devi Anugrah, M.Pd. Pelaksanaan kegiatan PkM di sekolah, peserta disetiap sekolah siswa dan guru dibagi menjadi 4 kelompok dan narasumber dibagi 2 kelompok karena mengingat jarak sekolah dan waktu. Setiap kelompok diberikan peralatan dan media untuk bekerjasama melaksanakan intruksi narasumber. Narasumber juga diharuskan mendampingi semua kelompok untuk memastikan pekerjaannya dilakukan dengan benar.

\section{HASIL DAN PEMBAHASAN}

Pelaksanaan kegiatan pelatihan pembuatan kerajinan dengan bahan dasar tulang daun melalui proses dekomposisi berlangsung pada hari Senin, 7 Januari 2019
SMP 2 Banyuputih dan Selasa 8 Januari 2019 di SMA N 1 Banyuputih. Waktu kegiatan dimualai dari jam 08.00 WIB s.d 14.00 WIB. Peserta di SMP 2 Banyuputih terdiri dari 35 orang peserta yang terdiri dari 33 siswa-siswi dan 2 guru, Sedangkan di SMA N 1 Banyuputih terdiri dari 28 orang peserta yang terdiri dari 27 siswa-siswi dan 1 guru. Kegiatan pengabdian masyarakat ini mengambil mitra sekolah yang fakus pada siswa siswi sekolah karena materi yang diberikan adalah pemanfaatan tulang daun untuk membuat kerajinan bagi siswa-siswi. Pembuatan kerajinan dengan memanfaatkan daundaun disekitar sekolah merupakan salah satu bentuk pembelajaran dalam bidang biologi. Hal tersebut dilakukan mengingat banyaknya sumber hayati di lingkungan sekitar yang sangat berpotensi untuk dimanfaatkan yaitu slah satunya membuat kerajinan tangan (McLaren \& Turkington, 2011).

Dalam pembelajaran biologi, kegiatan membuat kerajinan dari bahan tulang daun adalah penting karena selain siswa-siswi dapat membuat kerajinan, kegiatan ini juga memerikan pengalaman kepada siswa dan guru untuk melihat secara langsung struktur tulang daun dari berbagai tanaman. Kegiatan pembelajaran di kelas umumnya memuat teori-teori dasar tentang tanaman. Dengan adanya pelatihan ini tentu akan membantu siswa dan guru mengenal lebih jauh dari struktur dan fisiologi dari tanaman.

Pelajaran biologi sebagai salah mata pelajaran yang mengandung unsur muatan lokal, tambahan materi yang digali dari kearifan lokal yang relevan sangat diperlukan untuk mengembangkan kreatifitas siswa. Indonesa merupakan salah satu negara yang memiliki potensi sumber daya alam yang besar khusunya biodiversitas tanaman. Banyaknya jumlah tanaman tersebut memberikan potensi untuk dioleh menjadi sebuah karya kerajinan yang dapat meningkatkan daya saing industri bangsa. Kegiatan membuat kerajinan 
berbahan dasar daun yang didekomposisi ini merupakan kerajinan yang memanfaatkan sumber daya local dari daun-daun yang telah gugur/rontok. Umumnya daun yang telah gugur tidak dimanfaatkan oleh manusia melainkan dibiarkan jatuh dan terdekomposisi oleh mikroba (Negassa et al., 2015).

Pada kegiatan pengabdian ini, tim dibantu oleh mahasiswa berusaha memberikan keterampilan memanfaatkan daun-daun yang rontok di sekitar lingkungan siswa untuk di ubah menjadi aneka kerajinan yang menarik. Daun yang telah gugur dipilih dengan kriteria masih memiliki struktur tulang lengkap dan daun belum rusak. Daun yang biasa digunakan untuk pembuatan awetan tulan daun adalah daun kupu-kupu, daun sirsak, daun nangka, daun mangga, daun bodi, dan lain-lain. Daun tersebut kemudian didekomposisi (direndam pada tanah selama 2 minggu) untuk menghilangkan daging atau jaringan daun yang banyak mengandung klorofil dengan cara mencuci pada rendaman air atau dapat juga disikat secara perlahan agar tulang daun tidak patah. Kemudian dilakukan pencucian lagi dengan merendam tualng daun dengan pemutih pakaian selama 30 menit. Setelah selesai, kemudian dilakukan pewarnaan dengan pewarna tekstil selama 20 menit. Langkah kerja selengkapnya terdapat pada lampiran. Hasil akhir tulang daun yang telah selesai seperti pada Gambar 1.

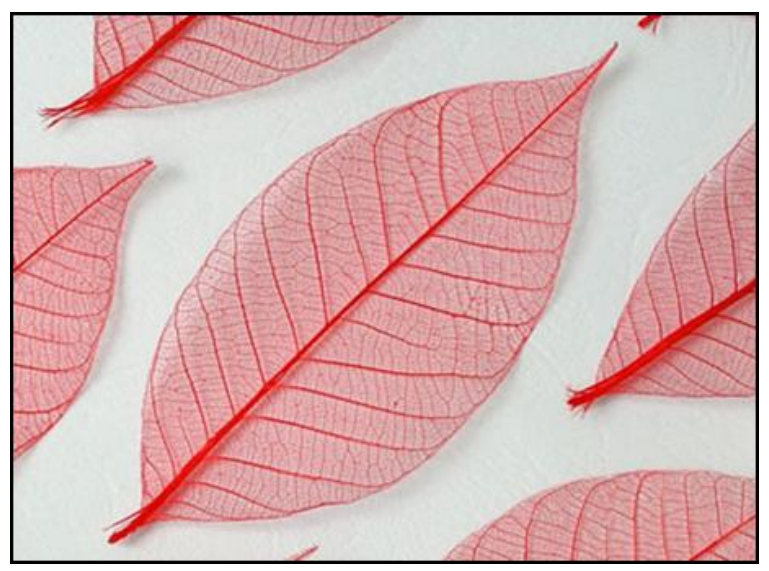

Gambar 1. Tulang daun yang telah diberi pewarna
Kegiatan pengabdian ini memiliki relevansi dengan kebutuhan guru di lapangan. Berdasarakan hasil survey sebelum pelaksanaan, guru-guru biologi masih mengalami kesulitan dalam memanfaatkan kearifan lokal dari daun untuk pembelajaran dan kerajinan. Dokumentasi praktek Mahasiswa disajikan pada Gambar 2.

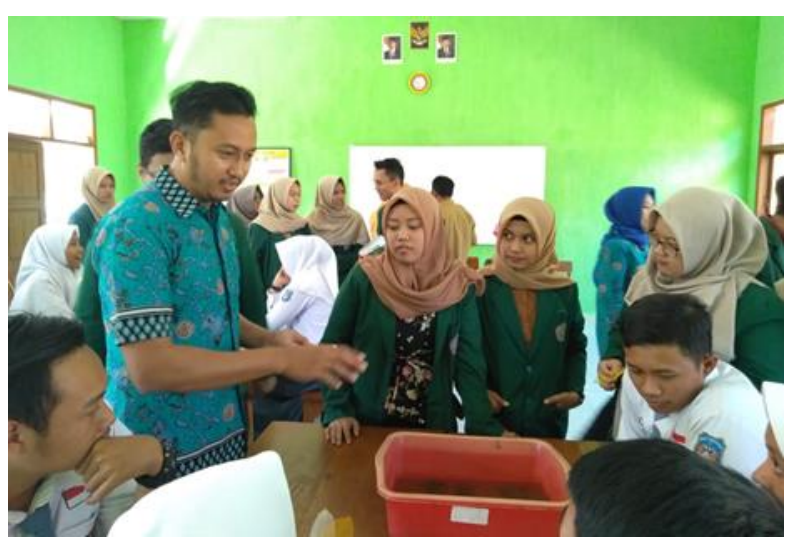

Gambar 2. Bapak Devi Anugrah, M.Pd dan mahasiswa mempraktekkan pembuatan kerajinan tulang daun

Pada kesempatan kegiatan pengabdian ini, tik pelaksana yang dibantu mahasiswa memberikan pelatihan bagaimana membuat kerajian berbahan dasar daun. Didampingi sejumlah mahasiswanya, bapak Devi Anugrah, M.Pd mempraktikkan cara pembuatan tulang daun di depan mahasiswa yang terdiri siswa-siswi kelas SMA Negeri 1 danSMP2 Banyuputih, Situbondo. Proses pengerjaannya cukup mudah dan dapat dilakukan di ruang kelas.

Dalam kegiatan tersebut, siswa siswi dan guru terlihat sangat antusias mengikuti kegiatan ini. Semua peserta berkesempatan mempraktekkan apa yang diajarkan oleh tim. Dokumentasi pendampingan Mahasiswa disajikan pada Gambar 3. 


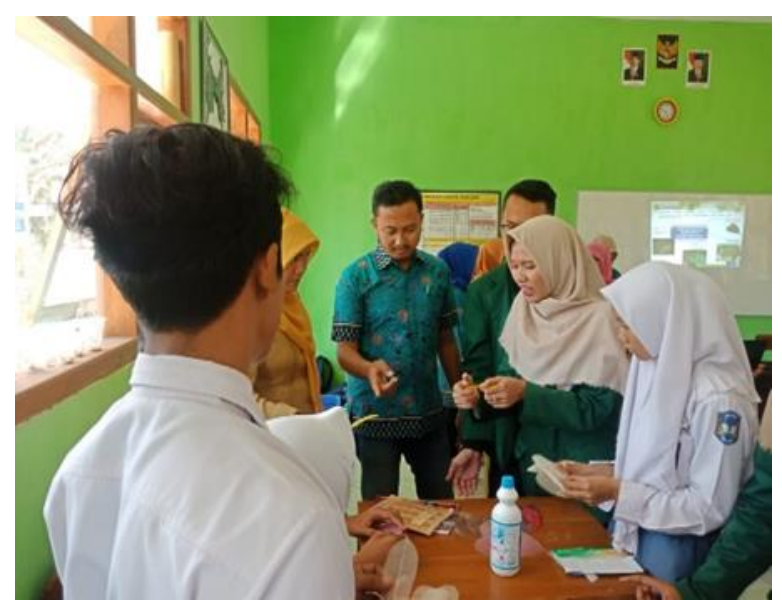

Gambar 3. Pendampingan mahasiswa dalam membuat kerajinan tulang daun

Pada awalnya mereka belum tahu bagaimana memanfaatkan kerajian berbahan dasar daun. Setelah mengikuti kegiatan ini, para peserta mengaku sangat senang dan bertambah pengalaman baik pengetahuan maupun ketrampilan. Jika sebelumnya daun yang telah gugur dianggap sebgai limbah yang tidak bermanfaat, melalui kegiatan ini mereka menyadari akan daya guna dari daun tersebut.

Kegiatan pengabdian membuat kerajinan dari tulang daun ini merupakan salah satu kegiatan untuk mendukung tercapainya Kurikulum 2013. Sebagai bagian dari Kurikulum 2013, pembelajaran bidang prakarya bagi peserta didik harus mencakup aktivitas dan materi pembelajaran yang dapat meningkatkan kompetensi pengetahuan, keterampilan, dan sikap untuk menciptakan sebuah karya yang bernilai ekonomi dari produk karya tersebut. Kegiatan membuat kerajinan tangan berbahan tulang daun yang didekomposisi ini adalah salah satu contoh konkret yang sesuai untuk peserta didik (Setyowati et al., 2014). Selain membantu memahami pelajaran biologi, kegiatan ini akan menumbuhkan jiwa kewirausahaan mereka.

Dengan merangsang daya imajinasi siswa untuk berkreatifitas, kini aneka limbah daun dapat diubah menjadi hiasan indah dan tampak memiliki nilai (Desniasih et al., 2015). Misalnya limbah dari tempat aneka jenis dan bentuk minuman kaleng, plastik be-kas bungus dari aneka sneck, sampah minuman gelas plastik, dan sejumlah aneka limbah dari berbagai jenis produk. Dari hasil kegiatan pengabdian ini, luaran utama yang dapat dihasilkan adalah meningkatnya ketrampilan dan pengetahuan membuat karya seni dari limbah yaitu daun.

\section{KESIMPULAN}

Kegiatan membuat kerajinan tulang daun sangat bermanfaat bagi bagi guru dan siswa-siswi di SMA N 1 dan SMP 2 Banyuputih, Situbondo. Pada umumnya siswa sangat senang dengan pembelajaran membuat kerajinan yang bahannya dapat ditemukan di lingkungan sekitar mereka. Lebih lanjut, pengembangan ketrampilan siswa dapat membantu siswa menumbuhkan jiwa kewirausahaan.

\section{UCAPAN TERIMA KASIH}

Ucapan terima kasih kami tujukan kepada pemberi dana kegiatan LPPM UHAMKA. Kami juga menyapaikan terima kasih kepada pihak-pihak yang membantu pelaksanaan kegiatan.

\section{REFERENSI}

Desniasih, N.W.P., Vipriyanti, N.U., Pastini, N.L. 2015. Pengembangan Usaha Ekonomi Produktif Kerajinan Pandan Dan Kontribusinya Terhadap Pendapatan Petani Di Desa Tulikup Kecamatan Gianyar Kabupaten Gianyar Bali. Agrimeta: Jurnal Pertanian Berbasis Keseimbangan Ekosistem. 5(10):21-25.

McLaren, J.R., Turkington, R. 2011. Plant Identity Influences Decomposition through More Than One Mechanism. PLoS ONE. 6(8):e23702. https://dx.doi.org/10.1371/journal.pone.002 3702

Muhajirin. 2018. Dasar-Dasar Kerajinan. Yogyakarta: Universitas Negeri Yogyakarta. 
Negassa, W.C., Guber, A.K., Kravchenko, A.N., Marsh, T.L., Hildebrandt, B., Rivers, M.L. 2015. Properties of Soil Pore Space Regulate Pathways of Plant Residue Decomposition and Community Structure of Associated Bacteria. PLoS ONE. 10(4):e0123999. https://dx.doi.org/10.1371/journal.pone.012 3999

Sarjani, T.M., Mawardi, Pandia, E.S., Wulandari, D. 2017. Identifikasi Morfologi Dan Anatomi Tipe Stomata Famili Piperaceae di Kota Langsa. IIPI (Jurnal IPA dan Pembelajaran IPA). 1(2):182-191. https://doi.org/10.24815/jipi.v1i2.9693

Setyowati, I., Naswati, W., Heatiningsih, Miftakhodin, Cahyadi, Ayu, D. 2014. Prakarya dan Kewirausahaan. Jakarta: Pusat Kurikulum dan Perbukuan Badan Penelitian dan Pengembangan Kementerian Pendidikan dan Kebudayaan Republik Indonesia.

Susilo, Amirullah, G. 2018. Pengelolaan dan Pemanfaatan Laboratorium Sekolah bagi Guru Muhammadiyah di Jakarta Timur. Jurnal Solma. 7(1):127-137. https://doi.org/10.29405/solma.v7i1.2380

Trilling, B., Fadel, C. 2009. 21st Century Skills: Learning for Life in Our Times. San Francisco, US: JosseyBass/John Wiley \& Sons, Inc.

Wahyuni, R.W., Hidayati, W. 2017. Peran Sekolah dalam Membentuk Keterampilan Wirausaha Berbasis Tauhid di SD Entrepreneur Muslim Alif-A Piyungan Bantul Yogyakarta. Manageria: Jurnal Manajemen Pendidikan Islam. 2(2):359-377.

https://doi.org/10.14421/manageria.2017.22 $-08$

Wardina, U.V., Jalinus, N., Asnur, L. 2019. Kurikulum Pendidikan Vokasi Pada Era Revolusi Industri 4.0. Jurnal Pendidikan. 20(1):82-90. https://doi.org/10.33830/jp.v20i1.240.2019

Wing, S., Ash, A., Ellis, B., Hickey, L.J. 1999. Manual of Leaf Architecture: Morphological description and categorization of dicotyledonous and net-veined monocotyledonous angiosperms. Washington, US: Leaf Architecture Working Group 